\title{
Mesenchymal stromal cells in renal ischemia/reperfusion injury
}

\author{
Dorottya K. de Vries ${ }^{1}$, Alexander F. M. Schaapherder ${ }^{1}$ and Marlies E. J. Reinders ${ }^{2}{ }^{*}$ \\ ${ }^{1}$ Department of Surgery, Leiden University Medical Center, Leiden, Netherlands \\ ${ }^{2}$ Department of Nephrology, Leiden University Medical Center, Leiden, Netherlands
}

\author{
Edited by: \\ Martin Johannes Hoogduijn, Erasmus \\ MC University Medical Center \\ Rotterdam, Netherlands \\ Reviewed by: \\ Frank J. M. F. Dor, Erasmus MC \\ University Medical Center Rotterdam, \\ Netherlands

\section{*Correspondence:} \\ Marlies E. J. Reinders, Department \\ of Nephrology, Leiden University \\ Medical Center, C3-P, PO Box 9600, \\ 2300 RC Leiden, Netherlands. \\ e-mail:m.e.j.reinders@lumc.nl
}

Ischemia/reperfusion (I/R) injury is an inevitable consequence of organ transplantation and a major determinant of patient and graft survival in kidney transplantation. Renal I/R injury can lead to fibrosis and graft failure. Although the exact sequence of events in the pathophysiology of I/R injury remains unknown, the role of inflammation has become increasingly clear. In this perspective, mesenchymal stromal cells (MSCs) are under extensive investigation as potential therapy for I/R injury, since MSCs are able to exert immune regulatory and reparative effects. Various preclinical studies indicate the beneficial effects of MSCs in ameliorating renal injury and accelerating tissue repair. These versatile cells have been shown to migrate to sites of injury and to enhance repair by paracrine mechanisms instead of by differentiating and replacing the injured cells. The first phase I studies of MSCs in human renal I/R injury and kidney transplantation have been started, and results are awaited soon. In this review, preliminary results and opportunities of MSCs in human renal I/R injury are summarized. We might be heading towards a cell-based paradigm shift in the treatment of renal I/R injury.

\section{Keywords: mesenchymal stromal cells, stem cells, ischemia/reperfusion injury, kidney transplantation}

\section{INTRODUCTION}

Ischemia/reperfusion ( $\mathrm{I} / \mathrm{R})$ injury is the exacerbation of tissue damage upon reestablishment of circulation after a period of ischemia. I/R injury is considered a major contributor to tissue damage in multiple clinical situations such as myocardial infarction, stroke, and organ transplantation. In many clinical settings, the duration of ischemia is beyond control, and preventive and therapeutical measures are required to reduce the extent of $\mathrm{I} / \mathrm{R}$ injury. Unfortunately, current treatment is primarily supportive. The pathophysiology of $\mathrm{I} / \mathrm{R}$ injury is multifactorial and only partially understood. However, the general local reaction to reperfusion is thought to involve an inflammatory response that leads to tissue damage. In the quest for new therapeutical options for renal I/R injury, stem cells have come into play. With their multipotent immune modulating properties they hold promise to lead to improvement in the treatment of renal I/R injury.

\section{PATHOPHYSIOLOGY OF ISCHEMIA/REPERFUSION INJURY}

Although there may be differences in the exact pathophysiological mechanisms of $\mathrm{I} / \mathrm{R}$ injury between different organs, some processes appear to play a universal role (Eltzschig and Eckle, 2011). The endothelium and microvasculature are very sensitive to hypoxia and easily affected in $\mathrm{I} / \mathrm{R}$ injury. Upon reperfusion, the vascular endothelial cell lining can undergo swelling which may lead to narrowing of the vascular lumen (Summers and Jamison, 1971; Leaf, 1973). Moreover, vasorelaxation can be impaired, together contributing to the no-reflow phenomenon (Lieberthal et al., 1989). Endothelial injury can increase microvascular permeability which may lead to inflammatory cell recruitment into the diseased organ. There have been many reports of invading granulocytes, monocytes, dendritic cells (DCs), and lymphocytes after reperfusion (Shigematsu et al., 2002; Burne-Taney et al., 2003; Day et al., 2005, 2006; de Vries et al., 2011).

Together with leukocytes, platelets can be activated by injured endothelium. In myocardial infarction, platelets mediate thrombotic occlusion and increase damage by contributing to the no-reflow phenomenon (Gawaz, 2004). However, platelets are also able to invade the tissue (Weissmuller et al., 2008). This is essential since platelets can contribute to the inflammatory response through release of cytokines, chemokines, and growth factors from their granules (Reed, 2004; Lisman and Porte, 2010; Thornton et al., 2010). In fact, platelets have been suggested to be involved in the inflammatory response of $\mathrm{I} / \mathrm{R}$ injury in various organs. They are able to roll and adhere to post-reperfusion endothelium in a P-selectin-dependent mechanism (Massberg et al., 1998; Sindram et al., 2000; Khandoga et al., 2002; am Esch et al., 2005). In mouse myocardial tissue, the first activated platelets are present within minutes after reperfusion (Xu et al., 2006), and then accumulate in the infarcted myocardium (Liu et al., 2011).

The ensuing inflammatory response is considered to exacerbate damage. Both the innate and the adaptive immune system can be activated after reperfusion. Activation of the innate immune system is probably mediated via pattern-recognition receptors such as toll-like receptors that recognize their endogenous ligands that are released upon tissue damage (Chen and Nunez, 2010). Besides, the complement system is part of the humoral immune response and can play a role both as first line innate defense, but may also contribute to the adaptive immune response (Dunkelberger and Song, 2010). In many animal experiments a role for (terminal) 
complement activation in I/R injury has been suggested (Zhou et al., 2000; Park et al., 2001; de Vries et al., 2003; Zheng et al., 2008; Zhang et al., 2011), although recent experiments doubt the involvement of the complement system itself in the initiation of injury (van der Pol et al., 2012). The role of complement activation in human I/R injury is even more complex. While in human myocardial I/R injury a role of complement activation was suggested (Yasojima et al., 1998; Baldwin etal., 1999), the diverse intervention studies using anti-complement therapy did not lead to major improvements (Granger et al., 2003; Mahaffey et al., 2003; Lazar et al., 2004; Verrier et al., 2004; Testa et al., 2008).

Ischemia-related metabolic adaptations and dysregulated mitochondrial homeostasis are thought to result in substantial release of reactive oxygen and nitrogen species (RONS) upon reintroduction of oxygen. The RONS overload can overwhelm the endogenous antioxidant system, resulting in oxidative damage. This may trigger secondary processes and contribute to the proinflammatory response upon reperfusion (Crimi et al., 2006; Valko et al., 2007; Gourdin etal., 2009; Misra etal., 2009). Numerous animal studies clearly demonstrated that antioxidant therapy ameliorates I/R injury (Ambrosio et al., 1991; Yellon and Hausenloy, 2007; Lakhan etal., 2009). Despite these findings, studies in humans consistently fail to show any clinically relevant effect (Land and Zweler, 1997; Bath et al., 2001; El-Hamamsy et al., 2007; Yellon and Hausenloy, 2007; Suzuki, 2009). The basis for this discrepancy between human and animal studies is still unclear, yet it may suggest that the contribution of RONS to I/R injury in humans is less than commonly thought.

Ultimately, when I/R injury to the cell is severe, various programs of cell death can be activated. There are three major forms of cell death: necrosis, apoptosis, and autophagy. Besides acute cell death during and directly after the ischemic period, cell death continues for several days following reperfusion. All three types of cell death can contribute to the continued loss of cells for days and even weeks in the reperfused tissue (Zhao et al., 2000, 2001). Autophagy during the ischemic episode appears to keep cells viable and might play a protective role. However, it is suggested that activation of autophagy after reperfusion is detrimental (Matsui et al., 2007; Hariharan et al., 2011).

\section{ISCHEMIA/REPERFUSION INJURY IN KIDNEY TRANSPLANTATION}

Ischemia/reperfusion injury is an inevitable consequence of kidney transplantation. Graft survival for living unrelated donation is superior compared to grafts from brain dead and cardiac dead donors, although the average human leukocyte antigen (HLA) matching is worse (Terasaki etal., 1995). Therefore, the poor graft survival of deceased donor kidneys cannot be exclusively attributed to differences in immunogenicity. I/R injury can induce delayed graft function and has a major influence on graft function and survival (Yarlagadda et al., 2009).

Inflammation is regarded the crucial event in the development of tissue injury and graft dysfunction in renal I/R injury. Many individual factors, such as cytokines and complement have been identified to be involved in the inflammatory response. However, intervention studies aiming at specific inhibition of a single factor have generally shown disappointing results (Park et al., 2001; de Vries etal., 2009). Cooperation, redundancy, and interactions play a role and mechanisms appear to be more complex than previously thought. Pharmacological inhibition of the entire inflammatory cascade would appear a logical intervention, however, the negative side effects appear larger than the anticipated beneficial effects (Morariu et al., 2005).

\section{ISCHEMIA/REPERFUSION INJURY: LONG-TERM IMPACT}

Although short-term results of kidney transplantation are excellent, 5 year graft loss can be up to $30 \%$ in older recipients (Keith et al., 2006). Protocol biopsies obtained in the first years after transplantation have shown interstitial fibrosis/tubular atrophy (IF/TA). This finding has been correlated with later allograft dysfunction and loss (Nankivell et al., 2003; Park et al., 2010). Both allogen dependent and independent factors determine IF/TA. I/R injury is an important non-allogeneic factor and the duration of the cold ischemic period is directly correlated to delayed graft function and even allograft failure (Ojo et al., 1997; Salahudeen et al., 2004). I/R injury itself, without allogeneic transplantation, has been shown to cause interstitial fibrosis and glomerulosclerosis in experimental models (Tullius et al., 1994; Herrero-Fresneda et al., 2000; Basile et al., 2001; Figure 1).

\section{RENAL REPAIR}

In recent years, it has become clear that in response to kidney injury not only fibrotic repair but also restoration of damaged kidney tissue can occur. This has been best established for acute kidney injury, where surviving resident tubular epithelial cells dedifferentiate and subsequently re-enter the cell cycle to replace the necrotic tubular epithelium. Dedifferentiated cells outside the injured kidney may also migrate to the site of injury within the kidney. Kidney biopsies in male recipients of a female donor kidney with acute tubular necrosis showed presence of the male $\mathrm{Y}$ chromosome in renal tubular cells. No Y chromosome staining was seen in patients without acute tubular necrosis. This provides evidence that extrarenal cells participate in renal regeneration (Poulsom et al., 2001; Gupta et al., 2002).

The call for better treatment strategies for $I / R$ injury has directed research toward more encompassing cellular-based therapies, particularly aimed at the use of stem cells. The multi-factorial pathophysiology of I/R injury makes a pharmacological agent that has a single mechanistic target less likely to be therapeutically effective. In contrast, stem cells are versatile, and able to target a whole cascade of repair mechanisms simultaneously and successively, thereby improving organ protection and repair.

\section{MESENCHYMAL STROMAL CELLS}

Of all bone marrow (bm)-derived cells, mesenchymal stromal cells (MSCs) hold special promise in attenuating kidney injury, since nephrons are largely of mesenchymal origin and stromal cells are of crucial importance for signaling leading to differentiation of both nephrons and collecting ducts. MSCs are characterized by three main criteria: (1) The ability to differentiate into osteoblasts, adipocytes, and chondroblasts in vitro, (2) the expression of surface makers CD73, CD90, and CD105, and lack of expression of haematopoietic markers including CD34 and CD45, and (3) plastic adherence in culture (Dominici et al., 2006). 


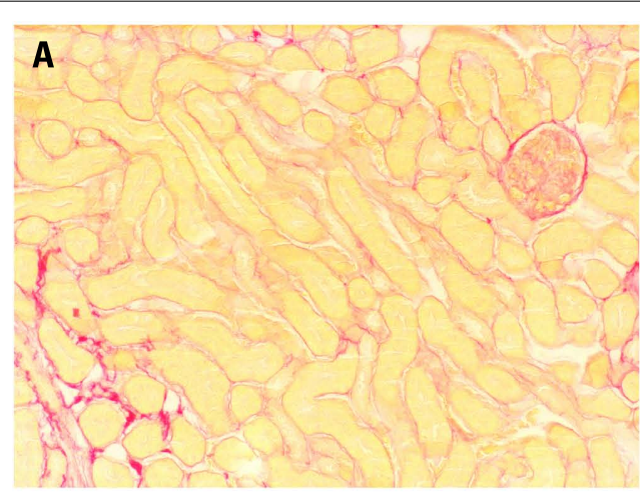

FIGURE 1 | Male, 8-week-old BI6 mice underwent bilateral (warm) renal ischemia for $\mathbf{2 5} \mathbf{m i n}$ by clamping of the renal artery and vein. Long-term structural damage and fibrosis were assessed. I/R injury induced severe patchy renal fibrosis three weeks after ischemia, although

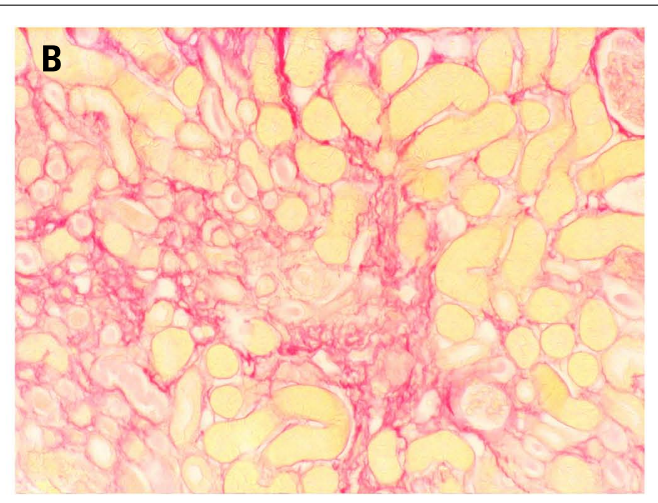

kidney function partially recovered. Sirius red staining shows (A) normal mouse kidney and (B) severe fibrosis 3 weeks after the mouse underwent 25 min of warm renal I/R injury (Representative images, unpublished data).
Mesenchymal stromal cells have the ability to secrete numerous growth factors and cytokines that collectively stimulate mitogenesis, inhibit apoptosis, and modulate immune responses. They can alter cytokine secretion profiles of T cells (Krampera et al., 2003), DCs, and natural killer cells to induce a more anti-inflammatory or tolerant phenotype (Aggarwal and Pittenger, 2005; Stagg, 2007). These immune modulating effects could be achieved both with autologous and allogeneic MSCs.

An important aspect of the effect of MSCs is their ability to home to areas of injury or inflammation. Exogenously administered MSCs can engraft into various injured structures in the kidney (Ninichuk et al., 2006; Herrera et al., 2007; Wong et al., 2008). Recently, studies have shed light on the exact factors that facilitate homing of MSCs. Amid them, CD44 and hyaluronic acid interactions, and stromal-derived factor-1 (SDF-1) and CXCR4 interactions may be crucial in recruiting exogenous MSCs to injured renal (Togel et al., 2005b; Herrera et al., 2007).

\section{SOURCES OF MSCS}

While initially isolated from the bm, MSCs have now been identified within most tissues and are thought to represent a perivascular cell population involved in normal tissue homeostasis (Crisan et al., 2008). Indeed, MSCs have been isolated from adipose tissue, umbilical cord (uc) blood, placenta, and various organs (Zuk et al., 2002; Morigi et al., 2004; Toma et al., 2005; da Silva et al., 2006; Hoogduijn et al., 2006). Recently, MSCs have also been isolated from the human and mouse kidney. In mice these cells were extensively compared to bmMSCs (Pelekanos et al., 2012). Transcriptome and immunophenotype analysis of the renal MSClike populations supported strong congruence with bmMSCs. Future studies need to elucidate whether regeneration and functional repair can be enhanced via the resident renal stem cells. In the meantime, bmMSCs are the best characterized population and currently more than 200 clinical trials are ongoing using bmMSCs ${ }^{1}$.

\footnotetext{
${ }^{1}$ www.clinicaltrials.gov
}

\section{MSCS AMELIORATE RENAL ISCHEMIA/REPERFUSION INJURY IN VIVO}

Although MSCs most probably do not replace damaged cells, evidence on beneficial effects of MSCs in renal I/R injury is accumulating in animal experiments. Intravenous injection of bm-derived lineage-negative pluripotent cells after experimental renal I/R significantly attenuated the creatinine rise (Duffield et al., 2005). Peripherally administered purified MSCs significantly attenuated functional and histological damage (Furuichi et al., 2012). Even when administered $24 \mathrm{~h}$ or later after I/R injury, MSCs still were able to ameliorate damage and fibrosis (Lange et al., 2005; Togel et al., 2005a; Donizetti-Oliveira et al., 2012). In experimental renal allograft transplantation MSCs decreased inflammation (Hara et al., 2011).

Different studies have reported beneficial effects of human MSCs on acute repair in the kidney (Morigi et al., 2006). The therapeutic potential of human bmMSCs was studied in immunodeficient NOD-SCID mice. Infused human bmMSCs reduced renal cell apoptosis and increased proliferation after cisplatininduced acute renal failure. bmMSCs also preserved the integrity of the tubular epithelium and peritubular vessels, and prolonged survival (Morigi et al., 2008). In search for new sources of MSCs for renal repair, human ucMSCs were shown to ameliorate both renal dysfunction and tubular cell injury, and prolong survival in cisplatin-induced acute kidney injury (Morigi et al., 2010).

The mechanism of MSC-induced kidney repair has been the subject of numerous studies. There is growing evidence that the process of transdifferentiation is probably not relevant to renal repair in vivo. The primary means of these cells most likely involve paracrine and endocrine effects; including mitogenic, anti-apoptotic, anti-inflammatory, antifibrotic, and angiogenic influences (Figure 2; Ninichuk et al., 2006). The factors that mediate the paracrine effects are obviously of great interest. Several factors that are abundant in MSCconditioned medium have been mentioned (Togel et al., 2007). Recently, it was suggested that microvesicles released from MSCs may account for this paracrine mechanism. Administration of isolated microvesicles from human MSCs indeed protected 


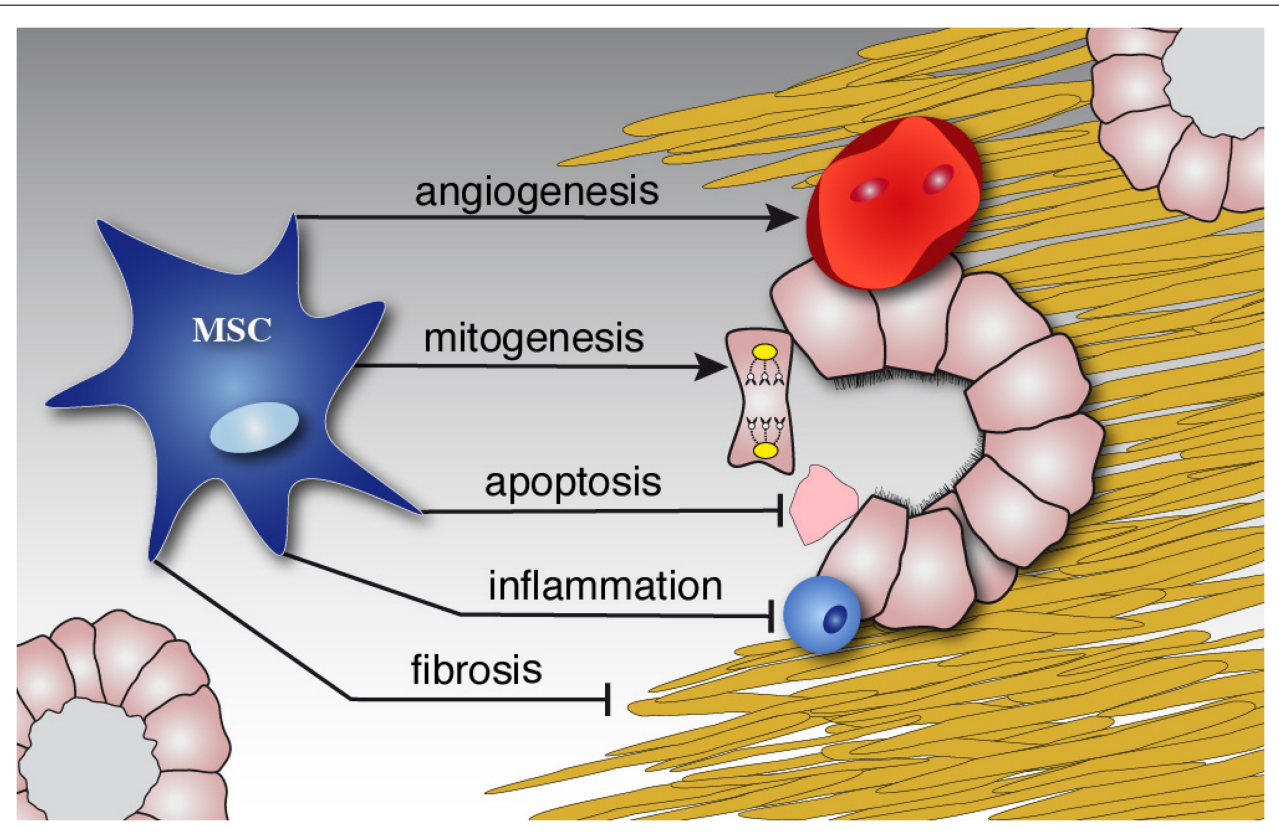

FIGURE 2 | MSCs diminish damage and induce repair. Schematic illustration of the paracrine effects of MSCs on the kidney. While stimulating repair by mitogenic and angiogenic effects, MSCs inhibit ongoing inflammation, apoptosis and later fibrosis of injured tissue. rats from acute ischemic kidney injury (Bruno etal., 2009; Gatti et al., 2011).

\section{CLINICAL APPLICATIONS OF MSCs IN RENAL DISEASE}

There are only limited clinical data about MSC therapy in renal disease. The first safety and feasibility data of autologous MSC administration in the week after kidney transplantation were published in 2011 (Perico et al., 2011). Although data are limited to two patients, MSC infusion appeared feasible and restricted memory $\mathrm{T}$ cell expansion while enlarging Treg population. However, both patients showed transient increase in serum creatinine levels within 2 weeks after cell infusion that might be related to intragraft recruitment of granulocytes, suggesting that timing of infusion is of particular importance (Ortiz et al., 2003; Fang et al., 2004; Lange et al., 2005). This is probably related to the necessity for the appropriate micro-environment to allow MSCs to acquire their anti-inflammatory properties. In addition, in a recent study the use of autologous MSCs resulted in lower incidence of acute rejection, decreased risk of opportunistic infection and better estimated renal function at 1 year compared with anti-IL-2 receptor antibody as induction therapy (Tan et al., 2012). In our clinical trial we investigate safety and feasibility of autologous bmMSC treatment in patients with subclinical rejection and/or IF/TA in the renal biopsy at 4 weeks or 6 months after renal transplantation (Clinical trials NCT00734396). Hereby we expect to provide additional information about the importance of timing in the transplant setting.

\section{AUTOLOGOUS VERSUS ALLOGENEIC MSCs}

Until now, most studies have focused on the use of autologous cells since allogeneic cell transplantation may promote allograft rejection and possibly sensitization (Nauta et al., 2006; Stagg et al., 2006). However, autologous MSCs also have disadvantages. The cells need weeks of culture and a concern for the use of autologous MSCs includes their potential dysfunction due to the underlying disease. Few studies have reported influence of renal failure on MSC behavior. In mice, functional incompetence of MSCs was reported under uremic conditions (Noh et al., 2012). In addition, in human MSCs it was shown that uremic serum induced an osteoblast-like phenotype in MSCs accompanied by matrix remodeling and calcification (Kramann etal., 2011). In contrast, it was recently shown that human adipose tissuederived MSCs are not affected by renal disease (Roemeling-van Rhijn et al., 2012).

\section{MSC NUMBER, ROUTE OF ADMINISTRATION, AND INTERACTION WITH IMMUNOSUPPRESSIVES}

Alongside the cell source, the number of MSCs and the timing of administration are critical. In most clinical trials doses of 0.4 to $10 \times 10^{6} / \mathrm{kg}$ body weight were used (Lazarus et al., 2005; Le Blanc et al., 2008; Macmillan et al., 2009). However, no clear correlations have been made between cell dose and clinical effect. Dose escalation studies to monitor safety and efficacy are one of the major objectives for future studies of MSCs.

Mesenchymal stromal cells have been administered intravenously in most human trials. Other possible successful routes of administration include intra-arterial or intra-renal infusion (Kunter et al., 2006, 2007; Ding et al., 2009). An advantage of these routes may be the direct administration at the place of injury, whereas disadvantages include the complexity and possible side effects such as obstruction of capillaries. To date, there are no reports of these treatment modalities in humans. 
Current immunosuppressive drugs cannot be withheld from patients receiving MSC treatment after renal transplantation. Therefore, it is of importance that an optimal concurrent immunosuppressive regimen is chosen in which drugs have no negative impact on MSC function and vice versa. So far, this interaction has mainly been assessed by in vitro studies (Maccario et al., 2005; Prevosto et al., 2007) and future studies are needed to elucidate their interaction with concurrent immunosuppression in vivo in order to facilitate successful translation to the clinic.

\section{POSSIBLE HURDLES OF MSC TREATMENT}

Although cell therapy with MSCs holds enormous promise for the treatment of many diseases, unwanted side effects of MSC infusions must be assessed with the greatest care. Experimental studies have demonstrated maldifferentiation after injecting MSCs directly into damaged tissue (Breitbach et al., 2007; Kunter etal., 2007). In addition, MSCs may adopt and unwanted, myofibroblast-like phenotype after administration ( $\mathrm{Wu}$ et al., 2003; di Bonzo et al., 2008). Another important concern is that MSCs may differentiate into neoplastic cells or may cause promotion of tumor cell growth (Djouad et al., 2003; Karnoub et al., 2007; Tolar etal., 2007), although an increased risk of tumor formation has never been confirmed in humans (Centeno et al., 2010). Currently, more than 2000 patients have been treated with

\section{REFERENCES}

Aggarwal, S., and Pittenger, M. F. (2005). Human mesenchymal stem cells modulate allogeneic immune cell responses. Blood 105, 1815-1822. am Esch, J. S. II, Tustas, R. Y., Robson, S. C., Hosch, S. B., Akyildiz, A., Broring, D. C., Fischer, L., Knoefel, W. T., and Rogiers, X. (2005). Recipient levels and function of von Willebrand factor prior to liver transplantation and its consumption in the course of grafting correlate with hepatocellular damage and outcome. Transpl. Int. 18, 1258-1265.

Ambrosio, G., Flaherty, J. T., Duilio, C., Tritto, I., Santoro, G., Elia, P. P., Condorelli, M., and Chiariello, M. (1991). Oxygen radicals generated at reflow induce peroxidation of membrane lipids in reperfused hearts. J. Clin. Invest. 87, 2056-2066.

Baldwin, W. M. III, Samaniego-Picota, M., Kasper, E. K., Clark, A. M., Czader, M., Rohde, C., Zachary, A. A., Sanfilippo, F., and Hruban, R. H. (1999). Complement deposition in early cardiac transplant biopsies is associated with ischemic injury and subsequent rejection episodes. Transplantation 68, 894-900.

Basile, D. P., Donohoe, D., Roethe, K., and Osborn, J. L. (2001). Renal ischemic injury results in permanent damage to peritubular capillaries and influences long-term function. Am. J. Physiol. Renal Physiol. 281, F887F899.
Bath, P. M., Iddenden, R., Bath, F. J., and Orgogozo, J. M. (2001). Tirilazad for acute ischaemic stroke. Cochrane Database Syst. Rev. CD002087.

Breitbach, M., Bostani, T., Roell, W., Xia, Y., Dewald, O., Nygren, J. M., Fries, J. W., Tiemann, K., Bohlen, H., Hescheler, J., Welz, A., Bloch, W., Jacobsen, S. E., and Fleischmann, B. K. (2007). Potential risks of bone marrow cell transplantation into infarcted hearts. Blood 110, 1362-1369.

Bruno, S., Grange, C., Deregibus, M. C., Calogero, R. A., Saviozzi, S., Collino, F., Morando, L., Busca, A., Falda, M., Bussolati, B., Tetta, C., and Camussi, G. (2009). Mesenchymal stem cell-derived microvesicles protect against acute tubular injury. J. Am. Soc. Nephrol. 20, 1053-1067.

Burne-Taney, M. J., Ascon, D. B., Daniels, F., Racusen, L., Baldwin, W., and Rabb, H. (2003). B cell deficiency confers protection from renal ischemia reperfusion injury. $J$. Immunol. 171, 3210-3215.

Centeno, C. J., Schultz, J. R., Cheever, M., Robinson, B., Freeman, M., and Marasco, W. (2010). Safety and complications reporting on the re-implantation of cultureexpanded mesenchymal stem cells using autologous platelet lysate technique. Curr. Stem Cell Res. Ther. 5, 81-93.

Chen, G. Y., and Nunez, G. (2010). Sterile inflammation: sensing and

allogeneic or autologous MSCs worldwide for a variety of diseases and so far no major side effects have been reported. However, still little is known about long-term side effects.

\section{SUMMARY}

The pathophysiology of $\mathrm{I} / \mathrm{R}$ injury is complex and characterized by inflammation, leading to tissue injury and graft dysfunction. Given current shortage of donor organs and usage of marginal donor kidneys for transplantation, novel treatment options to minimize renal I/R injury are urgently needed. Recent developments in stem cell research and derived clinical stem cell therapies have given reason to believe that such cell-based treatments will become generally available in the near future. Although substantial additional time for the maturation of these therapies for routine clinical use is needed, the first steps of MSCbased therapeutic strategies in the treatment of $I / R$ injury have been taken.

\section{ACKNOWLEDGMENTS}

We thank The Netherlands Organization for Health Research and Development for the financial support: project AGIKO 92003525 (Dorottya K. de Vries) and TAS and Veni grant (Marlies E. J. Reinders). Gerrit Kracht is gratefully acknowledged for the design of Figure 2.

reacting to damage. Nat. Rev. Immunol. 10, 826-837.

Crimi, E., Sica, V., Williams-Ignarro, S., Zhang, H., Slutsky, A. S., Ignarro, L. J., and Napoli, C. (2006). The role of oxidative stress in adult critical care. Free Radic. Biol. Med. 40, 398-406.

Crisan, M., Yap, S., Casteilla, L., Chen, C. W., Corselli, M., Park, T. S., Andriolo, G., Sun, B., Zheng, B., Zhang, L., Norotte, C., Teng, P. N., Traas, J., Schugar, R., Deasy, B. M., Badylak, S., Buhring, H. J., Giacobino, J. P., Lazzari, L., Huard, J., and Peault, B. (2008). A perivascular origin for mesenchymal stem cells in multiple human organs. Cell Stem Cell 3, 301-313.

da Silva, M. L., Chagastelles, P. C., and Nardi, N. B. (2006). Mesenchymal stem cells reside in virtually all postnatal organs and tissues. J. Cell Sci. 119, 2204-2213.

Day, Y. J., Huang, L., Ye, H., Li, L., Linden, J., and Okusa, M. D. (2006). Renal ischemia-reperfusion injury and adenosine $2 \mathrm{~A}$ receptormediated tissue protection: the role of CD4+ T cells and IFN-gamma. $J$. Immunol. 176, 3108-3114.

Day, Y. J., Huang, L., Ye, H., Linden, J., and Okusa, M. D. (2005). Renal ischemia-reperfusion injury and adenosine $2 \mathrm{~A}$ receptormediated tissue protection: role of macrophages. Am. J. Physiol. Renal Physiol. 288, F722-F731. de Vries, B., Matthijsen, R. A., Wolfs, T. G., van Bijnen, A. A., Heeringa, P., and Buurman, W. A. (2003). Inhibition of complement factor C5 protects against renal ischemiareperfusion injury: inhibition of late apoptosis and inflammation. Transplantation 75, 375-382.

de Vries, D. K., Lindeman, J. H., Ringers, J., Reinders, M. E., Rabelink, T. J., and Schaapherder, A. F. (2011). Donor brain death predisposes human kidney grafts to a proinflammatory reaction after transplantation. Am. J. Transplant. 11, 1064-1070.

de Vries, D. K., Lindeman, J. H., Tsikas, D., de, Heer E., Roos, A., de Fijter, J. W., Baranski, A. G., van, Pelt J., and Schaapherder, A. F. (2009). Early renal ischemia-reperfusion injury in humans is dominated by IL-6 release from the allograft. Am. J. Transplant. 9, 1574-1584.

di Bonzo, L. V., Ferrero, I., Cravanzola, C., Mareschi, K., Rustichell, D., Novo, E., Sanavio, F., Cannito, S., Zamara, E., Bertero, M., Davit, A., Francica, S., Novelli, F., Colombatto, S., Fagioli, F., and Parola, M. (2008). Human mesenchymal stem cells as a two-edged sword in hepatic regenerative medicine: engraftment and hepatocyte differentiation versus profibrogenic potential. Gut 57, 223-231.

Ding, Y., Xu, D., Feng, G., Bushell, A., Muschel, R. J., and Wood, K. J. (2009). Mesenchymal stem cells prevent the 
rejection of fully allogenic islet grafts by the immunosuppressive activity of matrix metalloproteinase-2 and -9 . Diabetes 58, 1797-1806.

Djouad, F., Plence, P., Bony, C., Tropel, P., Apparailly, F., Sany, J., Noel, D., and Jorgensen, C. (2003). Immunosuppressive effect of mesenchymal stem cells favors tumor growth in allogeneic animals. Blood 102, 3837-3844.

Dominici, M., Le, B. K., Mueller, I., Slaper-Cortenbach, I., Marini, F., Krause, D., Deans, R., Keating, A., Prockop, D., and Horwitz, E. (2006). Minimal criteria for defining multipotent mesenchymal stromal cells. The International Society for Cellular Therapy position statement. Cytotherapy 8, 315-317.

Donizetti-Oliveira, C., Semedo, P., Burgos-Silva, M., Cenedeze, M. A., Malheiros, D. M., Reis, M. A., Pacheco-Silva, A., and Camara, N. O. (2012). Adipose tissue-derived stem cell treatment prevents renal disease progression. Cell Transplant. doi: 10.3727/096368911X623925 [Epub ahead of print].

Duffield, J. S., Park, K. M., Hsiao, L. L., Kelley, V. R., Scadden, D. T., Ichimura, T., and Bonventre, J. V. (2005). Restoration of tubular epithelial cells during repair of the postischemic kidney occurs independently of bone marrow-derived stem cells. J. Clin. Invest. 115, 1743-1755.

Dunkelberger, J. R., and Song, W. C. (2010). Complement and its role in innate and adaptive immune responses. Cell Res. 20, 34-50.

El-Hamamsy, I., Stevens, L. M., Carrier, M., Pellerin, M., Bouchard, D., Demers, P., Cartier, R., Page, P., and Perrault, L. P. (2007). Effect of intravenous $N$-acetylcysteine on outcomes after coronary artery bypass surgery: a randomized, double-blind, placebo-controlled clinical trial. J. Thorac. Cardiovasc. Surg. 133, 7-12.

Eltzschig, H. K., and Eckle, T. (2011). Ischemia and reperfusion - from mechanism to translation. Nat. Med. 17, 1391-1401.

Fang, B., Shi, M., Liao, L., Yang, S., Liu, Y., and Zhao, R. C. (2004). Systemic infusion of $\mathrm{FLK1}(+)$ mesenchymal stem cells ameliorate carbon tetrachloride-induced liver fibrosis in mice. Transplantation 78, 83-88.

Furuichi, K., Shintani, H., Sakai, Y., Ochiya, T., Matsushima, K., Kaneko, S., and Wada, T. (2012). Effects of adipose-derived mesenchymal cells on ischemia-reperfusion injury in kidney. Clin. Exp. Nephrol. doi: 10.1007/s10157-012-0614-6 [Epub ahead of print].

Gatti, S., Bruno, S., Deregibus, M. C., Sordi, A., Cantaluppi, V., Tetta, C., and Camussi, G. (2011). Microvesicles derived from human adult mesenchymal stem cells protect against ischaemia-reperfusioninduced acute and chronic kidney injury. Nephrol. Dial. Transplant. 26, 1474-1483.

Gawaz, M. (2004). Role of platelets in coronary thrombosis and reperfusion of ischemic myocardium. Cardiovasc. Res. 61, 498-511.

Gourdin, M. J., Bree, B., and De, K. M. (2009). The impact of ischaemiareperfusion on the blood vessel. Eur. J. Anaesthesiol. 26, 537-547.

Granger, C. B., Mahaffey, K. W., Weaver, W. D., Theroux, P., Hochman, J. S., Filloon, T. G., Rollins, S., Todaro, T. G., Nicolau, J. C., Ruzyllo, W., and Armstrong, P. W. (2003). Pexelizumab, an anti-C5 complement antibody, as adjunctive therapy to primary percutaneous coronary intervention in acute myocardial infarction: the COMplement inhibition in Myocardial infarction treated with Angioplasty (COMMA) trial. Circulation 108, 1184-1190.

Gupta, S., Verfaillie, C., Chmielewski, D., Kim, Y., and Rosenberg, M. E. (2002). A role for extrarenal cells in the regeneration following acute renal failure. Kidney Int. 62, 1285-1290.

Hara, Y., Stolk, M., Ringe, J., Dehne, T., Ladhoff, J., Kotsch, K., Reutzel-Selke, A., Reinke, P., Volk, H. D., and Seifert, M. (2011). In vivo effect of bone marrow-derived mesenchymal stem cells in a rat kidney transplantation model with prolonged cold ischemia. Transpl. Int. 24, 1112-1123.

Hariharan, N., Zhai, P., and Sadoshima, J. (2011). Oxidative stress stimulates autophagic flux during ischemia/reperfusion. Antioxid. Redox. Signal. 14, 2179-2190.

Herrera, M. B., Bussolati, B., Bruno, S., Morando, L., Mauriello-Romanazzi, G., Sanavio, F., Stamenkovic, I., Biancone, L., and Camussi, G. (2007). Exogenous mesenchymal stem cells localize to the kidney by means of CD44 following acute tubular injury. Kidney Int. 72, 430-441.

Herrero-Fresneda, I., Torras, J., Lloberas, N., Riera, M., Cruzado, J. M., Condom, E., Merlos, M., Alsina, J., and Grinyo, J. M. (2000). Cold ischemia in the absence of alloreactivity induces chronic transplant nephropathy through a process mediated by the platelet-activating factor. Transplantation 70, 1624-1631.
Hoogduijn, M. J., Gorjup, E., and Genever, P. G. (2006). Comparative characterization of hair follicle dermal stem cells and bone marrow mesenchymal stem cells. Stem Cells Dev. 15, 49-60.

Karnoub, A. E., Dash, A. B., Vo, A. P., Sullivan, A., Brooks, M. W., Bell, G. W., Richardson, A. L., Polyak, K., Tubo, R., and Weinberg, R. A. (2007). Mesenchymal stem cells within tumour stroma promote breast cancer metastasis. Nature 449, 557-563.

Keith, D. S., Cantarovich, M., Paraskevas, S., and Tchervenkov, J. (2006). Recipient age and risk of chronic allograft nephropathy in primary deceased donor kidney transplant. Transpl. Int. 19, 649-656.

Khandoga, A., Biberthaler, P., Enders, G., Teupser, D., Axmann, S., Luchting, B., Hutter, J., Messmer, K., and Krombach, F. (2002). Pselectin mediates platelet-endothelial cell interactions and reperfusion injury in the mouse liver in vivo. Shock 18, 529-535.

Kramann, R., Couson, S. K., Neuss, S., Kunter, U., Bovi, M., Bornemann, J., Knuchel, R., Jahnen-Dechent, W., Floege, J., and Schneider, R. K. (2011). Exposure to uremic serum induces a procalcific phenotype in human mesenchymal stem cells. Arterioscler. Thromb. Vasc. Biol. 31, e45-e54.

Krampera, M., Glennie, S., Dyson, J., Scott, D., Laylor, R., Simpson, E. and Dazzi, F. (2003). Bone marrow mesenchymal stem cells inhibit the response of naive and memory antigen-specific $\mathrm{T}$ cells to their $\operatorname{cog}$ nate peptide. Blood 101, 3722-3729.

Kunter, U., Rong, S., Boor, P., Eitner, F., Muller-Newen, G., Djuric, Z., van Roeyen, C. R., Konieczny, A., Ostendorf, T., Villa, L., MilovancevaPopovska, M., Kerjaschki, D., and Floege, J. (2007). Mesenchymal stem cells prevent progressive experimental renal failure but maldifferentiate into glomerular adipocytes. J. Am. Soc. Nephrol. 18, 1754-1764.

Kunter, U., Rong, S., Djuric, Z., Boor, P., Muller-Newen, G., Yu, D., and Floege, J. (2006). Transplanted mesenchymal stem cells accelerate glomerular healing in experimental glomerulonephritis. J. Am. Soc. Nephrol. 17, 2202-2212.

Lakhan, S. E., Kirchgessner, A., and Hofer, M. (2009). Inflammatory mechanisms in ischemic stroke: therapeutic approaches. J. Transl. Med. 7,97.

Land, W., and Zweler, J. L. (1997). Prevention of reperfusion-induced, free radical-mediated acute endothelial injury by superoxide dismutase as an effective tool to delay/prevent chronic renal allograft failure: a review. Transplant. Proc. 29, 2567 2568.

Lange, C., Togel, F., Ittrich, H., Clayton, F., Nolte-Ernsting, C., Zander, A. R., and Westenfelder, C. (2005). Administered mesenchymal stem cells enhance recovery from ischemia/reperfusion-induced acute renal failure in rats. Kidney Int. 68 , 1613-1617.

Lazar, H. L., Bokesch, P. M., van, L. F., Fitzgerald, C., Emmett, C., Marsh, H. C. Jr., and Ryan, U. (2004). Soluble human complement receptor 1 limits ischemic damage in cardiac surgery patients at high risk requiring cardiopulmonary bypass. Circulation 110, II274-II279.

Lazarus, H. M., Koc, O. N., Devine, S. M., Curtin, P., Maziarz, R. T., Holland, H. K., Shpall, E. J., McCarthy, P., Atkinson, K., Cooper, B. W. Gerson, S. L., Laughlin, M. J., Loberiza, F. R. Jr., Moseley, A. B., and Bacigalupo, A. (2005). Cotransplantation of HLA-identical sibling culture-expanded mesenchymal stem cells and hematopoietic stem cells in hematologic malignancy patients. Biol. Blood Marrow Transplant. 11, 389-398.

Le Blanc, K., Frassoni, F., Ball, L., Locatelli, F., Roelofs, H., Lewis, I., Lanino, E., Sundberg, B., Bernardo, M. E., Remberger, M., Dini, G., Egeler, R. M., Bacigalupo, A., Fibbe, W., and Ringden, O. (2008). Mesenchymal stem cells for treatment of steroid-resistant, severe, acute graft-versus-host disease: a phase II study. Lancet 371, 15791586.

Leaf, A. (1973). Cell swelling. A factor in ischemic tissue injury. Circulation $48,455-458$

Lieberthal, W., Wolf, E. F., Rennke, H. G., Valeri, C. R., and Levinsky, N. G. (1989). Renal ischemia and reperfusion impair endothelium-dependent vascular relaxation. Am. J. Physiol. 256, F894-F900.

Lisman, T., and Porte, R. J. (2010). The role of platelets in liver inflammation and regeneration. Semin. Thromb. Hemost. 36, 170-174.

Liu, Y., Gao, X. M., Fang, L., Jennings, N. L., Su, Y., Q X, Samson, A. L., Kiriazis, H., Wang, X. F., Shan, L., Sturgeon, S. A., Medcalf, R. L., Jackson, S. P., Dart, A. M., and Du, X. J. (2011). Novel role of platelets in mediating inflammatory responses and ventricular rupture or remodeling following myocardial infarction. 
Arterioscler. Thromb. Vasc. Biol. 31, 834-841.

Maccario, R., Podesta, M., Moretta, A., Cometa, A., Comoli, P., Montagna, D., Daudt, L., Ibatici, A., Piaggio, G., Pozzi, S., Frassoni, F., and Locatelli, F. (2005). Interaction of human mesenchymal stem cells with cells involved in alloantigenspecific immune response favors the differentiation of CD4+ T-cell subsets expressing a regulatory/suppressive phenotype. Haematologica 90, 516-525.

Macmillan, M. L., Blazar, B. R., DeFor, T. E., and Wagner, J. E. (2009). Transplantation of exvivo culture-expanded parental haploidentical mesenchymal stem cells to promote engraftment in pediatric recipients of unrelated donor umbilical cord blood: results of a phase I-II clinical trial. Bone Marrow Transplant. 43, 447-454.

Mahaffey, K. W., Granger, C. B., Nicolau, J. C., Ruzyllo, W., Weaver, W. D., Theroux, P., Hochman, J. S., Filloon, T. G., Mojcik, C. F., Todaro, T. G., and Armstrong, P. W. (2003). Effect of pexelizumab, an anti-C5 complement antibody, as adjunctive therapy to fibrinolysis in acute myocardial infarction: the COMPlement inhibition in myocardial infarction treated with thromboLYtics (COMPLY) trial. Circulation 108, 1176-1183.

Massberg, S., Enders, G., Leiderer, R., Eisenmenger, S., Vestweber, D., Krombach, F., and Messmer, K. (1998). Platelet-endothelial cell interactions during ischemia/reperfusion: the role of P-selectin. Blood 92, 507-515.

Matsui, Y., Takagi, H., Qu, X., Abdellatif, M., Sakoda, H., Asano, T., Levine, B., and Sadoshima, J. (2007). Distinct roles of autophagy in the heart during ischemia and reperfusion: roles of AMP-activated protein kinase and Beclin 1 in mediating autophagy. Circ. Res. 100, 914-922.

Misra, M. K., Sarwat, M., Bhakuni, P., Tuteja, R., and Tuteja, N. (2009). Oxidative stress and ischemic myocardial syndromes. Med. Sci. Monit. 15, RA209-RA219.

Morariu, A. M., Loef, B. G., Aarts, L. P. H. J., Rietman, G. W., Rakhorst, G., van Oeveren, W., and Epema, A. H. (2005). Dexamethasone: benefit and prejudice for patients undergoing on-pump coronary artery bypass grafting - a study on myocardial, pulmonary, renal, intestinal, and hepatic injury. Chest 128, 2677-2687.

Morigi, M., Benigni, A., Remuzzi, G., and Imberti, B. (2006). The regenerative potential of stem cells in acute renal failure. Cell Transplant. 15(Suppl. 1), S111-S117.

Morigi, M., Imberti, B., Zoja, C., Corna, D., Tomasoni, S., Abbate, M., Rottoli, D., Angioletti, S., Benigni, A., Perico, N., Alison, M., and Remuzzi, G. (2004). Mesenchymal stem cells are renotropic, helping to repair the kidney and improve function in acute renal failure. J. Am. Soc. Nephrol. 15, 1794-1804.

Morigi, M., Introna, M., Imberti, B., Corna, D., Abbate, M., Rota, C., Rottoli, D., Benigni, A., Perico, N., Zoja, C., Rambaldi, A., Remuzzi, A., and Remuzzi, G. (2008). Human bone marrow mesenchymal stem cells accelerate recovery of acute renal injury and prolong survival in mice. Stem Cells 26, 2075-2082.

Morigi, M., Rota, C., Montemurro, T., Montelatici, E., Lo, C., V, Imberti, B., Abbate, M., Zoja, C., Cassis, P., Longaretti, L., Rebulla, P., Introna, M., Capelli, C., Benigni, A., Remuzzi, G., and Lazzari, L. (2010). Lifesparing effect of human cord bloodmesenchymal stem cells in experimental acute kidney injury. Stem Cells 28, 513-522.

Nankivell, B. J., Borrows, R. J., Fung, C. L., O'Connell, P. J., Allen, R. D., and Chapman, J. R. (2003). The natural history of chronic allograft nephropathy. N. Engl. J. Med. 349, 2326-2333.

Nauta, A. J., Westerhuis, G., Kruisselbrink, A. B., Lurvink, E. G., Willemze, R., and Fibbe, W. E. (2006). Donorderived mesenchymal stem cells are immunogenic in an allogeneic host and stimulate donor graft rejection in a nonmyeloablative setting. Blood 108, 2114-2120.

Ninichuk, V., Gross, O., Segerer, S., Hoffmann, R., Radomska, E., Buchstaller, A., Huss, R., Akis, N., Schlondorff, D., and Anders, $\mathrm{H}$. J. (2006). Multipotent mesenchymal stem cells reduce interstitial fibrosis but do not delay progression of chronic kidney disease in collagen4A3-deficient mice. Kidney Int. 70, 121-129.

Noh, H., Yu, M. R., Kim, H. J., Jeon, J. S., Kwon, S. H., Jin, S. Y., Lee, J., Jang, J., Park, J. O., Ziyadeh, F., Han, D. C., and Lee, H. B. (2012). Uremia induces functional incompetence of bone marrow-derived stromal cells. Nephrol. Dial. Transplant. 27, 218-225.

Ojo, A. O., Wolfe, R. A., Held, P. J., Port, F. K., and Schmouder, R. L. (1997). Delayed graft function: risk factors and implications for renal allograft survival. Transplantation 63 , 968-974.
Ortiz, L. A., Gambelli, F., McBride, C., Gaupp, D., Baddoo, M., Kaminski, N., and Phinney, D. G. (2003). Mesenchymal stem cell engraftment in lung is enhanced in response to bleomycin exposure and ameliorates its fibrotic effects. Proc. Natl. Acad. Sci. U.S.A. 100, 8407-8411.

Park, P., Haas, M., Cunningham, P. N., Alexander, J. J., Bao, L., Guthridge, J. M., Kraus, D. M., Holers, V. M., and Quigg, R. J. (2001). Inhibiting the complement system does not reduce injury in renal ischemia reperfusion. J. Am. Soc. Nephrol. 12, 1383-1390.

Park, W. D., Griffin, M. D., Cornell, L. D., Cosio, F. G., and Stegall, M. D. (2010). Fibrosis with inflammation at one year predicts transplant functional decline. J. Am. Soc. Nephrol. 21, 1987-1997.

Pelekanos, R. A., Li, J., Gongora, M., Chandrakanthan, V., Scown, J., Suhaimi, N., Brooke, G., Christensen, M. E., Doan, T., Rice, A. M., Osborne, G. W., Grimmond, S. M., Harvey, R. P., Atkinson, K., and Little, M. H. (2012). Comprehensive transcriptome and immunophenotype analysis of renal and cardiac MSC-like populations supports strong congruence with bone marrow MSC despite maintenance of distinct identities. Stem Cell Res. 8, 58-73.

Perico, N., Casiraghi, F., Introna, M., Gotti, E., Todeschini, M., Cavinato, R. A., Capelli, C., Rambaldi, A., Cassis, P., Rizzo, P., Cortinovis, M., Marasa, M., Golay, J., Noris, M., and Remuzzi, G. (2011). Autologous mesenchymal stromal cells and kidney transplantation: a pilot study of safety and clinical feasibility. Clin. J. Am. Soc. Nephrol. 6, 412-422.

Poulsom, R., Forbes, S. J., HodivalaDilke, K., Ryan, E., Wyles, S., Navaratnarasah, S., Jeffery, R., Hunt, T., Alison, M., Cook, T., Pusey, C., and Wright, N. A. (2001). Bone marrow contributes to renal parenchymal turnover and regeneration. J. Pathol. 195, 229-235.

Prevosto, C., Zancolli, M., Canevali, P., Zocchi, M. R., and Poggi, A. (2007). Generation of CD4+ or CD8+ regulatory $\mathrm{T}$ cells upon mesenchymal stem cell-lymphocyte interaction. Haematologica 92, 881-888.

Reed, G. L. (2004). Platelet secretory mechanisms. Semin. Thromb. Hemost. 30, 441-450.

Roemeling-van Rhijn, M., Reinders, M. E., de Klein, A., Douben, H., Korevaar, S. S., Mensah, F. K., Dor, F. J., Ijzermans, J. N., Betjes, M. G.,
Baan, C. C., Weimar, W., and Hoogduijn, M. J. (2012). Mesenchymal stem cells derived from adipose tissue are not affected by renal disease. Kidney Int. doi: 10.1038/ki.2012.187. [Epub ahead of print]

Salahudeen, A. K., Haider, N., and May, W. (2004). Cold ischemia and the reduced long-term survival of cadaveric renal allografts. Kidney Int. 65 , 713-718.

Shigematsu, T., Wolf, R. E., and Granger, D. N. (2002). T-lymphocytes modulate the microvascular and inflammatory responses to intestinal ischemiareperfusion. Microcirculation 9, 99-109.

Sindram, D., Porte, R. J., Hoffman, M. R., Bentley, R. C., and Clavien, P. A. (2000). Platelets induce sinusoidal endothelial cell apoptosis upon reperfusion of the cold ischemic rat liver. Gastroenterology 118, 183-191.

Stagg, J. (2007). Immune regulation by mesenchymal stem cells: two sides to the coin. Tissue Antigens 69, 1-9.

Stagg, J., Pommey, S., Eliopoulos, N., and Galipeau, J. (2006). Interferongamma-stimulated marrow stromal cells: a new type of nonhematopoietic antigen-presenting cell. Blood 107, 2570-2577.

Summers, W. K., and Jamison, R. L. (1971). The no reflow phenomenon in renal ischemia. Lab. Invest. 25 , 635-643.

Suzuki, K. (2009). Anti-oxidants for therapeutic use: why are only a few drugs in clinical use? Adv. Drug Deliv. Rev. 61, 287-289.

Tan, J., Wu, W., Xu, X., Liao, L., Zheng, F., Messinger, S., Sun, X., Chen, J., Yang, S., Cai, J., Gao, X., Pileggi, A., and Ricordi, C. (2012). Induction therapy with autologous mesenchymal stem cells in living-related kidney transplants: a randomized controlled trial. JAMA 307, 1169-1177.

Terasaki, P. I., Cecka, J. M., Gjertson, D. W., and Takemoto, S. (1995). High survival rates of kidney transplants from spousal and living unrelated donors. N. Engl. J. Med. 333, 333-336.

Testa, L., Van Gaal, W. J., Bhindi, R., Biondi-Zoccai, G. G., Abbate, A., Agostoni, P., Porto, I., Andreotti, F., Crea, F., and Banning, A. P. (2008). Pexelizumab in ischemic heart disease: a systematic review and metaanalysis on 15,196 patients. J. Thorac. Cardiovasc. Surg. 136, 884-893.

Thornton, P., McColl, B. W., Greenhalgh, A., Denes, A., Allan, S. M., and Rothwell, N. J. (2010). Platelet interleukin-1alpha drives cerebrovascular inflammation. Blood 115 , 3632-3639. 
Togel, F., Hu, Z., Weiss, K., Isaac, J., Lange, C., and Westenfelder, C. (2005a). Administered mesenchymal stem cells protect against ischemic acute renal failure through differentiation-independent mechanisms. Am. J. Physiol. Renal Physiol. 289, F31-F42.

Togel, F., Isaac, J., Hu, Z., Weiss, K., and Westenfelder, C. (2005b). Renal SDF1 signals mobilization and homing of CXCR4-positive cells to the kidney after ischemic injury. Kidney Int. 67, 1772-1784.

Togel, F., Weiss, K., Yang, Y., Hu, Z., Zhang, P., and Westenfelder, C. (2007). Vasculotropic, paracrine actions of infused mesenchymal stem cells are important to the recovery from acute kidney injury. Am. J. Physiol. Renal Physiol. 292, F1626-F1635.

Tolar, J., Nauta, A. J., Osborn, M. J., Panoskaltsis, M. A., McElmurry, R. T., Bell, S., Xia, L., Zhou, N., Riddle, M., Schroeder, T. M., Westendorf, J. J., McIvor, R. S., Hogendoorn, P. C., Szuhai, K., Oseth, L., Hirsch, B., Yant, S. R., Kay, M. A., Peister, A., Prockop, D. J., Fibbe, W. E., and Blazar, B. R. (2007). Sarcoma derived from cultured mesenchymal stem cells. Stem Cells 25, 371-379.

Toma, J. G., McKenzie, I. A., Bagli, D., and Miller, F. D. (2005). Isolation and characterization of multipotent skin-derived precursors from human skin. Stem Cells 23, 727-737.

Tullius, S. G., Heemann, U., Hancock, W. W., Azuma, H., and Tilney, N. L. (1994). Long-term kidney isografts develop functional and morphologic changes that mimic those of chronic allograft rejection. Ann. Surg. 220, 425-432.

Valko, M., Leibfritz, D., Moncol, J., Cronin, M. T., Mazur, M., and Telser, J. (2007). Free radicals and antioxidants in normal physiological functions and human disease. Int. J. Biochem. Cell Biol. 39, 44-84.

van der Pol, P., Schlagwein, N., van Gijlswijk, D. J., Berger, S. P., Roos, A., Bajema, I. M., de Boer, H. C., de Fijter, J. W., Stahl, G. L., Daha, M. R., and van, K. C. (2012). Mannan-binding lectin mediates renal ischemia/reperfusion injury independent of complement activation. Am. J. Transplant. 12, 877-887.

Verrier, E. D., Shernan, S. K., Taylor, K. M., Van de Werf, F., Newman, M. F., Chen, J. C., Carrier, M., Haverich, A., Malloy, K. J., Adams, P. X., Todaro, T. G., Mojcik, C. F., Rollins, S. A., and Levy, J. H. (2004). Terminal complement blockade with pexelizumab during coronary artery bypass graft surgery requiring cardiopulmonary bypass: a randomized trial. JAMA 291, 2319-2327.

Weissmuller, T., Campbell, E. L., Rosenberger, P., Scully, M., Beck, P. L., Furuta, G. T., and Colgan, S. P. (2008). PMNs facilitate translocation of platelets across human and mouse epithelium and together alter fluid homeostasis via epithelial cellexpressed ecto-NTPDases. J. Clin. Invest. 118, 3682-3692.

Wong, C. Y., Cheong, S. K., Mok, P. L., and Leong, C. F. (2008). Differentiation of human mesenchymal stem cells into mesangial cells in postglomerular injury murine model. Pathology 40, 52-57.

Wu, G. D., Nolta, J. A., Jin, Y. S., Barr, M. L., Yu, H., Starnes, V. A., and Cramer, D. V. (2003). Migration of mesenchymal stem cells to heart allografts during chronic rejection. Transplantation 75, 679-685.

Xu, Y., Huo, Y., Toufektsian, M. C., Ramos, S. I., Ma, Y., Tejani, A.
D., French, B. A., and Yang, Z. (2006). Activated platelets contribute importantly to myocardial reperfusion injury. Am. J. Physiol. Heart Circ. Physiol. 290, H692-H699.

Yarlagadda, S. G., Coca, S. G., Formica, R. N. Jr., Poggio, E. D., and Parikh, C. R. (2009). Association between delayed graft function and allograft and patient survival: a systematic review and meta-analysis. Nephrol. Dial. Transplant. 24, 1039-1047.

Yasojima, K., Schwab, C., McGeer, E. G., and McGeer, P. L. (1998). Human heart generates complement proteins that are upregulated and activated after myocardial infarction. Circ. Res. 83, 860-869.

Yellon, D. M., and Hausenloy, D. J. (2007). Mechanisms of disease: Myocardial reperfusion injury. $N$. Engl. J. Med. 357, 1121-1135.

Zhang, J., Hu, W., Xing, W., You, T., Xu, J., Qin, X., and Peng, Z. (2011). The protective role of CD59 and pathogenic role of complement in hepatic ischemia and reperfusion injury. Am. J. Pathol. 179, 2876-2884.

Zhao, Z. Q., Nakamura, M., Wang, N. P., Wilcox, J. N., Shearer, S., Ronson, R. S., Guyton, R. A., and Vinten-Johansen, J. (2000). Reperfusion induces myocardial apoptotic cell death. Cardiovasc. Res. 45, 651-660.

Zhao, Z. Q., Velez, D. A., Wang, N. P., Hewan-Lowe, K. O., Nakamura, M., Guyton, R. A., and Vinten-Johansen, J. (2001). Progressively developed myocardial apoptotic cell death during late phase of reperfusion. Apoptosis 6, 279-290.

Zheng, X., Zhang, X., Feng, B., Sun, H., Suzuki, M., Ichim, T., Kubo, N., Wong, A., Min, L. R., Budohn, M. E., Garcia, B., Jevnikar, A. M., and Min,
W. P. (2008). Gene silencing of complement C5a receptor using siRNA for preventing ischemia/reperfusion injury. Am. J. Pathol. 173, 973-980.

Zhou, W., Farrar, C. A., Abe, K., Pratt, J. R., Marsh, J. E., Wang, Y., Stahl, G. L., and Sacks, S. H. (2000). Predominant role for C5b-9 in renal ischemia/reperfusion injury. J. Clin. Invest. 105, 1363-1371.

Zuk, P. A., Zhu, M., Ashjian, P., De Ugarte, D. A., Huang, J. I., Mizuno, H., Alfonso, Z. C., Fraser, J. K., Benhaim, P., and Hedrick, M. H. (2002). Human adipose tissue is a source of multipotent stem cells. Mol. Biol. Cell 13, 4279-4295.

Conflict of Interest Statement: The authors declare that the research was conducted in the absence of any commercial or financial relationships that could be construed as a potential conflict of interest.

Received: 16 March 2012; paper pending published: 06 April 2012; accepted: 30 May 2012; published online: 02 July 2012.

Citation: de Vries DK, Schaapherder AFM and Reinders MEJ (2012) Mesenchymal stromal cells in renal ischemia/reperfusion injury. Front. Immun. 3:162. doi: 10.3389/fimmu.2012.00162

This article was submitted to Frontiers in Alloimmunity and Transplantation, a specialty of Frontiers in Immunology. Copyright (C) 2012 de Vries, Schaapherder and Reinders. This is an open-access article distributed under the terms of the Creative Commons Attribution Non Commercial License, which permits noncommercial use, distribution, and reproduction in other forums, provided the original authors and source are credited. 